\title{
An unusual presentation of purine nucleoside phosphorylase deficiency mimicking systemic juvenile idiopathic arthritis complicated by macrophage activation syndrome
}

\author{
Alessia Arduini ${ }^{1}$, Emiliano Marasco², Giulia Marucci ${ }^{2}$, Manuela Pardeo², Antonella Insalaco $^{2}$, Ivan Caiello², \\ Gian Marco Moneta ${ }^{2}$, Giusi Prencipe ${ }^{2}$, Fabrizio De Benedetti ${ }^{2}$ and Claudia Bracaglia ${ }^{2^{*}}$ (1)
}

\begin{abstract}
Background: Systemic juvenile idiopathic arthritis (sJIA) is an inflammatory condition that presents with fever, rash and arthritis. At onset systemic features are predominant and the diagnosis may be a challenge. Secondary hemophagocytic lymphohistiocytosis (sHLH) forms may be associated with different disorders, including rheumatic diseases, and this form is called macrophage activation syndrome (MAS). CXCL9 levels, a chemokine induced by IFNY, are significantly elevated in patients with sHLH or MAS and are correlated with laboratory features of disease activity. High levels of IL-18 have been reported in patients with MAS during sJIA, as well as in some patients with SHLH and IL-18 is indeed known to induce IFNy production.
\end{abstract}

Findings: We report a patient with a clinical presentation highly suggestive for systemic juvenile idiopathic arthritis (SJIA) onset complicated by MAS, and was later diagnosed with purine nucleoside phosphorylase (PNP)-deficiency with HLH. Some unusual features appeared when HLH was controlled and further investigations provided the correct diagnosis. Serum CXCL9 and IL-18 levels were found markedly elevated at disease onset, during the active phase of MAS and decreased progressively during the course.

Conclusion: The reported case underlines the potential difficulties in discriminating SJIA from other causes of systemic inflammation. Furthermore, this supports the notion that especially in young children with a sJIA-like disease other mimicking conditions should be actively sought for. CXCL9 and IL-18 levels suggested that patients with PNP-deficiency may have a subclinical activation of the IFNY pathway and indeed they are predisposed to develop sHLH.

Keywords: Macrophage activation syndrome, Juvenile idiopathic arthritis, Interferons, Interleukins, Chemokines

\footnotetext{
*Correspondence: claudia.bracaglia@opbg.net

${ }^{2}$ Division of Rheumatology, IRCCS Ospedale Pediatrico Bambino Gesù, Piazza

S. Onofrio 4, 00165 Rome, Italy

Full list of author information is available at the end of the article
}

(c) The Author(s). 2019 Open Access This article is distributed under the terms of the Creative Commons Attribution 4.0 International License (http://creativecommons.org/licenses/by/4.0/), which permits unrestricted use, distribution, and reproduction in any medium, provided you give appropriate credit to the original author(s) and the source, provide a link to the Creative Commons license, and indicate if changes were made. The Creative Commons Public Domain Dedication waiver (http://creativecommons.org/publicdomain/zero/1.0/) applies to the data made available in this article, unless otherwise stated. 


\section{Findings}

The onset of systemic juvenile idiopathic arthritis (sJIA) is characterized by quotidian fever associated with rash and arthritis. Arthritis may become evident later. Laboratory features of sJIA are not specific and include marked increase in acute-phase reactants and in platelet and white blood cell counts. The onset of sJIA may also be complicated by occurrence of macrophage activation syndrome (MAS). MAS, a severe, potentially fatal, complication of sJIA, is classified among the secondary forms of haemophagocytic lymphohistiocytosis (HLH), as an HLH occurring in the context of a rheumatic disease $[1,2]$.

Other secondary HLH (sHLH) forms may be associated with infections, malignancy or metabolic disorders. Primary HLH are caused by mutations of genes coding for proteins involved in cytotoxic activity or occur in the context of immunodeficiency. In a significant number of cases an underlying trigger cannot be found [3].

\section{Methods}

Serum chemokine (C-X-C motif) ligand 9 (CXCL9) levels and interleukin-18 (IL-18) levels were measured with ELISA (DuoSet ELISA KIT, R\&D Systems, Minneapolis, Minnesota and Medical and Biologic Laboratories, Nagoya, Japan, respectively).

Peripheral blood mononuclear cells (PBMCs) were isolated with Ficoll density gradient centrifugation. Lymphocytes subsets analysis was performed by cytometry [4]. To assess T cell proliferation, $10^{6} / \mathrm{mL}$ PBMCs were cultured with $1.5 \mu \mathrm{g} / \mathrm{mL}$ of anti-CD3 (clone OKT3) or with $4 \mu \mathrm{g} / \mathrm{mL}$ of phytohemoagglutinin (PHA) for three days. Proliferation was assessed with a standard $\left[{ }^{3} \mathrm{H}\right]$-thymidine incorporation assay. Degranulation of NK and T cells was assessed incubating PBMCs with K562 cells overnight followed by measurement of the translocation of CD107a to the cell surface by flow cytometry.

Parents provided an informed consent. The local Institutional Ethical Committee approved the study (number 1649/2018).

\section{Results}

A 14 months-old Caucasian male, born by vaginal delivery, (normal birth weight and normal APGAR score) from non-consanguineous parents, was admitted with persistent fever of 2 weeks duration, palpable cervical lymph nodes, rash, pericardial effusion and arthralgia. On suspicion of Kawasaki disease he had been treated with two doses $(2 \mathrm{~g} / \mathrm{kg})$ of intravenous immunoglobulins without response. The neonatal period was regular, he had not infection, growing normally. At age of 7 months, the paediatrician observed a neurological delay, no investigation was performed. At first examination, he appeared generally unwell with a maculopapular rash on face and legs. Cardiovascular, respiratory and abdominal were unremarkable. He developed overt swelling of wrists and ankles, with evidence of tenosynovitis on ultrasound. CRP and ESR were elevated. Leukopenia with lymphopenia and anaemia were present. Serum ferritin, lactate dehydrogenase, aspartate aminotransferase and triglyceride levels were markedly elevated (Table 1). Bone marrow biopsy showed hemophagocytosis. No infections were detected. Chest X-ray was negative. Echocardiography showed a pericardial effusion. Abdominal ultrasound did not reveal splenomegaly or hepatomegaly. Based on the presence of arthritis, with tenosynovitis, in a child with fever, rash and pericarditis, a diagnosis of sJIA was made, with onset complicated by MAS. Treatment with glucocorticoid (3 pulses of methylprednisolone $30 \mathrm{mg} / \mathrm{kg} /$ day), followed by oral prednisone $(2 \mathrm{mg} / \mathrm{kg} / \mathrm{die})$, and anakinra $(4 \mathrm{mg} / \mathrm{Kg} / \mathrm{die})$ was started with progressive improvement. Perforin expression and CD107 degranulation test were normal (Fig. 1a, b), sIL2 receptor was not measured; genetic analysis of the primary HLH related genes (PRF1, RAB27a, SH2D1A, STX11, STXBP2, XIAP, UNC13D, LYST) was negative.

After two weeks, laboratory parameters normalized except for persistent anaemia $(\mathrm{Hb} 8.9 \mathrm{~g} / \mathrm{dl})$ and variable lymphopenia $(500-900 / \mu \mathrm{L})$. Moreover, a mild muscle hypotonicity became apparent confirmed by neurological evaluation. Additional laboratory investigations revealed reduced haptoglobin $(<1 \mathrm{mg} / \mathrm{dl})$, high reticulocyte count $(9.34 \%)$ and positive Coombs test, all suggestive of haemolytic anaemia. Immunological phenotyping revealed a normal frequency of NK cells (33\%), B cells (5\%) and $\mathrm{T}$ cells $(53 \%)$, whereas absolute numbers of $\mathrm{CD}^{+}{ }^{+}(185$ cells $/ \mu \mathrm{L})$ and $\mathrm{CD}^{+}(211$ cells $/ \mu \mathrm{L}) \mathrm{T}$ cells were reduced. The $\mathrm{T}$ cell compartment showed expansion of a subpopulation of $\mathrm{CD} 3^{+} \mathrm{CD} 4^{-} \mathrm{CD} 8^{-}$expressing the $\gamma \delta$-TCR (no expansion of $\mathrm{CD}^{+}{ }^{+} \mathrm{CD} 4^{-} \mathrm{CD} 8^{-} \alpha \beta-\mathrm{TCR}$ was observed) and absence of proliferative response to PHA and OKT3 (Fig. 1c, d). A metabolic screening showed increase in urine orotic acid $(50.2 \mathrm{M} / \mathrm{mM})$, with normal citrulline serum level $(25 \mathrm{micromol} / \mathrm{l})$ and low serum level of uric acid $(0.1 \mathrm{mg} / \mathrm{dl})$. Based on the presence of haemolytic anaemia, $\mathrm{T}$ lymphocyte defect and increase in urinary orotic acid, purine nucleoside phosphorylase (PNP)-deficiency was suspected. Gene targeted sequencing of the PNP gene showed a novel missense mutation in exon 5 (c.595A $>\mathrm{C}$ coding for the p.S199R substitution), inherited by the father who is heterozygous. The mother did not carry any evident variant in the gene. A chromosomal microarray analysis with a mean $100 \mathrm{~Kb}$ resolution was performed (Cyto-SNS850K) showed a de novo microdeletion encompassing $448 \mathrm{~Kb}$ in the 14q11.2 region, that comprises the PNP gene. The 
Table 1 Laboratory parameters and cytokine levels during disease course

\begin{tabular}{|c|c|c|c|c|}
\hline Laboratory parameters & Onset & $\begin{array}{l}2 \text { weeks after HLH-treatment } \\
\text { was started }\end{array}$ & 6 weeks before HSCT & 12 months after $\mathrm{HSCT}$ \\
\hline White blood counts $\left(6-17 \times 10^{3} / \mathrm{uL}\right)$ & 3.4 & 14.54 & 5.4 & 10.1 \\
\hline Neutrophils $\left(1.68-8.5 \times 10^{3} / \mathrm{uL}\right)$ & 2.33 & 12.51 & 3.86 & 4.3 \\
\hline Lymphocytes (3-11.2 × 103/uL) & 0.5 & 0.34 & 0.62 & 8.51 \\
\hline Haemoglobin $(10.5-15.5 \mathrm{~g} / \mathrm{dl})$ & 7.1 & 8.0 & 8.0 & 10.9 \\
\hline Platelet $\left(150-450 \times 10^{3} / \mathrm{uL}\right)$ & 360 & 377 & 406 & 393 \\
\hline Ferritin $(17-390 \mathrm{ng} / \mathrm{ml})$ & 24,716 & 25 & 2051 & 34 \\
\hline Fibrinogen (200-500 mg/dl) & 253 & 240 & 219 & 208 \\
\hline D-dimer (< 0.5 microg/ml) & 2.81 & 0.35 & 0.5 & 0.25 \\
\hline PTT (25-34 s) & 27.3 & 25.2 & 33 & 31.9 \\
\hline PT (12.1-14.5s) & 13 & 13.4 & 12 & 13.3 \\
\hline PT RATIO-INR (0.92-1.14 s) & 1.07 & 1.13 & 0.92 & 1.07 \\
\hline Triglycerides (40-150 mg/dl) & 247 & 111 & 316 & 110 \\
\hline AST (5-40 UI/L) & 97 & 40 & 48 & 32 \\
\hline $\operatorname{ALT}(5-40$ UI/L) & 27 & 18 & 14 & 34 \\
\hline LDH (100-600 UI/L) & 2217 & 525 & 869 & 385 \\
\hline CRP $(0-0.5 \mathrm{mg} / \mathrm{dl})$ & 4.18 & $<0.05$ & 0.07 & 0.05 \\
\hline IL-18 (pg/ml) $)^{\mathrm{a}}$ & 250,000 & 83,200 & 113,789 & 1024 \\
\hline $\operatorname{CXCL9}(\mathrm{pg} / \mathrm{ml})^{\mathrm{a}}$ & 3556 & 4942 & 3327 & $<300$ \\
\hline
\end{tabular}

AST aspartate aminotransferase, $A L T$ alanine aminotransferase, $L D H$ lactate dehydrogenase, $C R P$ C-reactive protein, $H S C T$ hematopoietic stem cell transplantation ${ }^{\mathrm{a}}$ The values for IL-18 and CXCL9 established in healthy controls are: mean $265.0 \mathrm{pg} / \mathrm{ml}$, IQR 221.3-305.1 pg/ml for IL-18 and 612.4 pg/ml, IQR $429.5-801.5$ pg/ml for CXCL9

father did not carry this deletion. The p.S199R substitution is considered damaging in the Polyphen-2 software. The functional relevance of this genotype was confirmed by the marked reduction of PNP enzymatic activity $(0.57 \mu \mathrm{mol} / \mathrm{h} / \mathrm{ml}$ in the patient, normal value $>25$ micro$\mathrm{mol} / \mathrm{h} / \mathrm{ml})$.

The patient received an haplohydentical hematopoietic stem cell transplantation (HSCT) from his mother with subsequent progressive clinical improvement. At last follow-up, 12 months after HSCT, he was in good clinical conditions, laboratory parameters were completely normal and his neurological impairment improved (Table 1).

Serum levels of IL-18 and of CXCL9, a chemokine directly induced by interferon-gamma (IFN $\gamma$ ), were markedly elevated at disease onset. They decreased progressively during disease course and normalized after the HSCT (Table 1).

\section{Discussion}

We describe a patient with an onset highly suggestive for sJIA with MAS who was later diagnosed as having PNP-deficiency with HLH. Some unusual laboratory features that become apparent when HLH was controlled with glucocorticoids, i.e. persistent anaemia and persistent lymphopenia, led to additional investigations. While lymphopenia is usually present during MAS, it is not a feature of sJIA without MAS. Anaemia is typical of sJIA. The mean corpuscular volume was normal for age (ranging from 74 to $82 \mathrm{fL}$, with $\mathrm{Hb}$ ranging from 7.2 to $8.0 \mathrm{mg} / \mathrm{dl}$ ), this being rather unusual for persistent severe anaemia associated with sJIA, that is usually microcytic [5]. Moreover, when the general conditions improved hypotonicity became evident. Altogether, persistent lymphopenia, severe normocytic anaemia and hypotonicity were not consistent with sJIA with MAS. The following investigations led to the diagnosis: low $\mathrm{T}$ cell count with defective response to mitogens suggestive of immunodeficiency, low haptoglobin with positive Coomb's test suggestive of haemolytic anaemia and increased urinary orotic acid, a known intermediate metabolite of the pyrimidine biosynthetic pathway, suggestive of an alteration of purine salvage pathway. These findings were consistent with a diagnosis of PNP-deficiency.

PNP-deficiency is a rare autosomal recessive immunodeficiency caused by a mutation in the PNP gene that encodes for one of the enzymes involved in purine salvage [6, 7]. Defect in PNP leads to intracellular accumulation of metabolites, particularly deoxyguanosine triphostate (dGTP) which is toxic for neurons and $\mathrm{T}$ lymphocytes. PNP-deficiency is characterized by a progressive combined immunodeficiency, neurologic symptoms and autoimmune disorders. Patients present with bacterial, viral, and opportunistic infections. Approximately 


\section{a}

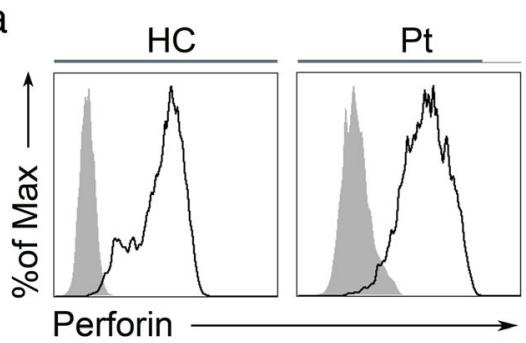

b

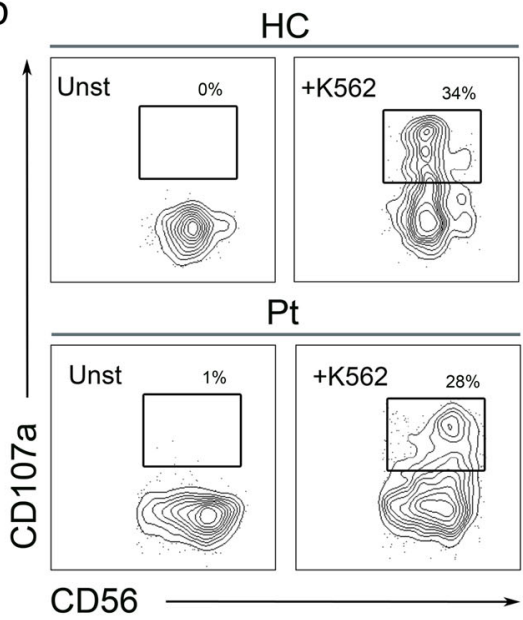

C

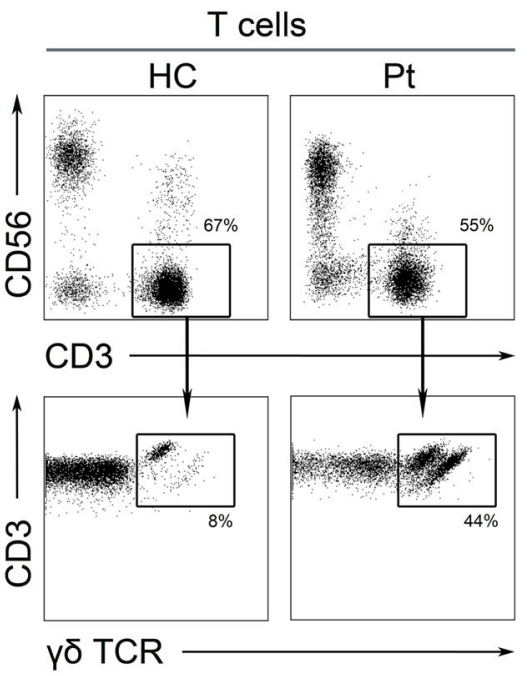

d

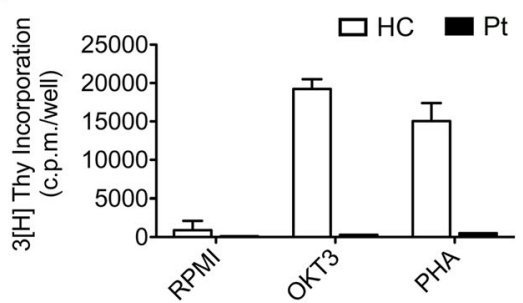

Fig. 1 Immunological functional tests of the patient. Intracellular expression of perforin in CD56 ${ }^{+}$NK cells was assessed by flow cytometry (a). Degranulation potential of $\mathrm{CD}_{56}{ }^{+} \mathrm{NK}$ cells was assessed by flow cytometry after overnight co-culture with target cells K562. Plots show the surface expression of CD107a on unstimulated and stimulated NK cells (b). Lymphocytes subsets were analysed by flow cytometry: T cells were identified as $\mathrm{CD}^{+} \mathrm{CD}^{-} 6^{-} \mathrm{CD} 19^{-}$; within the $\mathrm{CD}^{+}$gate, $\gamma \delta-\mathrm{T}$ cells were gated as $\mathrm{CD}^{+} \gamma \delta-\mathrm{TCR}^{+} \mathrm{a} \beta-\mathrm{TCR}^{-}$(c). $\mathrm{T}$ cell proliferation was assessed by a standard [ ${ }^{3} \mathrm{H}$-thymidine incorporation assay following stimulation with anti-CD3 (OKT3) or PHA (d). The results are shown for first determination while on $2 \mathrm{mg} / \mathrm{Kg}$ of methylprednisolone. They were repeated on a lower dose of oral prednisone $(0.25 \mathrm{mg} / \mathrm{Kg})$ with similar results

two-thirds of the patients have progressive neurologic symptoms, including developmental delay, muscle spasticity, ataxia, and pyramidal signs. The incidence of autoimmune disorders, including haemolytic anaemia, is increased [8-10]. Cases of HLH associated with PNP-deficiency have been reported [11].

Our patient fulfilled the HLH-2004 diagnostic criteria for primary HLH (5 out of 8 criteria, fever, cytopenia of two lines, increased ferritin, increased triglycerides and hemophagocytosis) [12]. Based on persistent fever, arthritis with tenosynovitis, rash and pericarditis, the presentation was consistent with sJIA. Duration of arthritis was shorter than 6 weeks, as per ILAR classification criteria [13], possibly due to rapid initiation of glucocorticoids because of overt HLH. $\mathrm{He}$ also met the classification criteria for MAS [14]. If we apply the MAS/primary HLH (MH) score, a score that may allow to distinguish patients with HLH from those with MAS during sJIA, our patient was more likely to have MAS [15].
Levels of IL-18 were markedly elevated (hundreds of $\mathrm{ng} / \mathrm{ml}$ ), in the range of those found in patients with MAS during sJIA in our lab (unpublished) and by Weiss et al. [16]. High IL-18 levels have been described in one patient with PNP-deficiency [17]. IL-18 is indeed known to induce IFNY production [18] and IFNY has been hypothesized to be a major pathogenic mediator of all forms of HLH [19]. High levels of IL-18 may therefore contribute to the predisposition of PNP-deficiency patients to develop HLH. Indeed, our patient had also high circulating levels of CXCL9, a chemokine induced by IFN $\gamma$, known to be significantly elevated in patients with all HLH forms, including MAS, and to be correlated with laboratory features of disease activity [16, 20, 21].

In summary, this patient had clinical and laboratory features, as well as elevated IL-18, consistent with sJIA and MAS. However, unusual clinical and laboratory findings suggested additional investigations that led to the diagnosis of PNP-deficiency mandating a significant change in therapeutic approach with urgent HSCT 
followed by prompt recovery. This case underlines the difficulties in discriminating sJIA from other causes of systemic inflammation. Furthermore, it supports the notion that, especially in young children with an sJIA-like disease, other mimicking conditions should be actively sought for, and underscores the need for in-depth longitudinal observations of clinical and laboratory features even when classification criteria for sJIA and for MAS complicating sJIA are met.

\section{Abbreviations}

Anti-CD3: Cluster of differentiation 3; CRP: C reactive protein; CXCL9: (C-X-C motif) ligand 9; dGTP: Deoxyguanosine triphostate; ESR: Erythrocyte sedimentation rate; HLH: Haemophagocytic lymphohistiocytosis; HSCT: Hematopoietic stem cell transplantation; IFNY: Interferon-gamma; IL18: Circulating Interleukin-18; MAS: Macrophage activation syndrome; PBMCs: Peripheral blood mononuclear cells; PHA: Phytohemoagglutinin pHLH: Primary or familial haemophagocytic; lymphohistiocytosis; PNP: Purine nucleoside phosphorylase; sHLH: Secondary or acquired haemophagocytic lymphohistiocytosis; sJIA: Systemic Juvenile Idiopathic Arthritis

\section{Acknowledgements}

Not applicable.

\section{Funding}

Fabrizio De Benedetti received research funding from Hoffmann-La Roche, Novimmune, Novartis, Abbvie, SOBI. All other authors declare that do not have any financial interest that could create a potential conflict of interest.

\section{Availability of data and materials}

All the data and materials presented in the manuscript are available in the table in the manuscript and in the references listed below.

\section{Authors' contributions}

AA wrote the manuscript; EM and GMM conducted the immunological analysis and wrote the immunological section; GM and MP reviewed the literature and wrote the manuscript; IC and GP conducted the cytokine analysis and wrote the section on cytokine results; AI and FDB reviewed the manuscript; $C B$ wrote the discussion and reviewed the manuscript. All authors read and approved the final manuscript.

\section{Ethics approval and consent to participate}

The Ethical Committee of IRCCS Ospedale Pediatrico Bambino Gesù, Study number 1649/2018, Protocol number 1038, approved the study. A written consent to participate to the study was collected from the patient's parents.

\section{Consent for publication}

A consent for publication was collected from the patient's parents.

\section{Competing interests}

Alessia Arduini, Emiliano Marasco, Giulia Marucci, Manuela Pardeo, Antonella Insalaco, Ivan Caiello, Gian Marco Moneta, Giusi Prencipe and Claudia Bracaglia declare that they have no competing interests. Fabrizio De Benedetti declares competing interests with Novartis, Novimmune, Hoffmann-La Roche, SOBI, AbbVie.

\section{Publisher's Note}

Springer Nature remains neutral with regard to jurisdictional claims in published maps and institutional affiliations.

\section{Author details}

${ }^{1}$ Pediatric Department, La Sapienza University of Rome, Rome, Italy. ${ }^{2}$ Division of Rheumatology, IRCCS Ospedale Pediatrico Bambino Gesù, Piazza S.

Onofrio 4, 00165 Rome, Italy.

Received: 18 January 2019 Accepted: 8 May 2019

Published online: 22 May 2019

\section{References}

1. Martini A. Systemic juvenile idiopathic arthritis. Autoimmun Rev. 2012;12:56-9.

2. Ravelli A, Grom AA, Behrens EM, Cron RQ. Macrophage activation syndrome as part of systemic juvenile idiopathic arthritis: diagnosis, genetics, pathophysiology and treatment. Genes Immun. 2012;13:289-98.

3. Xu XJ, Tang YM, Song H, Yang SL, Xu WQ, Zhao N, et al. Diagnostic accuracy of a specific cytokine pattern in hemophagocytic lymphohistiocytosis in children. J Pediatr. 2012;160:984-90.

4. Wersto RP, Chrest FJ, Leary JF, Morris C, Stetler-Stevenson MA, Gabrielson E. Doublet discrimination in DNA cell-cycle analysis. Cytometry. 2001 Oct 15;46:296-306.

5. Cazzola M, Ponchio L, de Benedetti F, Ravelli A, Rosti V, Beguin Y, et al. Defective iron supply for erythropoiesis and adequate endogenous erythropoietin production in the anemia associated with systemic-onset juvenile chronic arthritis. Blood. 1996;87:4824-30.

6. Cohen A, Staal GE, Ammann AJ, Martin DW. JR. Orotic aciduria in two unrelated patients with inherited deficiencies of purine nucleoside phosphorylase. J Clin Invest. 1977:60:491-4.

7. Markert ML, Finkel BD, McLaughlin TM, Watson TJ, Collard HR, McMahon CP et al. Mutations in purine nucleoside phosphorylase deficiency. Hum Mutat. 1997;9:118-21.

8. Giblett ER, Ammann AJ, Wara DW, Sandman R, Diamond LK. Nucleosidephosphorylase deficiency in a child with severely defective T-cell immunity and normal B-cell immunity. Lancet. 1975;1:1010-3.

9. Parvaneh N, Ashrafi MR, Yeganeh M, Pouladi N, Sayarifar F, Parvaneh L. Progressive multifocal leukoencephalopathy in purine nucleoside phosphorylase deficiency. Brain and Development. 2007;29:124-6.

10. Markert ML. Purine nucleoside phosphorylase deficiency. Immunodefic Rev. 1991;3:45-81.

11. Grunebaum E, Roifman CM. Gene abnormalities in patients with Hemophagocytic Lymphohistiocytosis. Isr Med Assoc J. 2002;4:366-9.

12. Henter Jl, Horne A, Aricó M, Egeler RM, Filipovich AH, Imashuku S, et al. HLH-2004: diagnostic and therapeutic guidelines for hemophagocytic lymphohistiocytosis. Pediatr Blood Cancer. 2007:48:124-31.

13. Petty RE, Southwood TR, Manners P, Baum J, Glass DN, Goldenberg J, et al. International league of associations for rheumatology classification of juvenile idiopathic arthritis: second revision, Edmonton, 2001. J Rheumatol. 2004;31:390-2.

14. Ravelli A, Minoia F, Davì S, Horne AC, Bovis F, Pistorio A, et al. 2016 classification criteria for macrophage activation syndrome complicating systemic juvenile idiopathic arthritis: a European league against rheumatism/American College of Rheumatology/Paediatric rheumatology international trials organisation collaborative initiative. Ann Rheum Dis. 2016;75:481-9.

15. Minoia F, Bovis F, Davì S, Insalaco A, Lehmberg K, Shenoi S, et al. Development and initial validation of the macrophage activation syndrome/primary Hemophagocytic Lymphohistiocytosis score, a diagnostic tool that differentiates primary Hemophagocytic Lymphohistiocytosis from macrophage activation syndrome. J Pediatr. 2017;189:72-8.

16. Weiss ES, Girard-Guyonvarc'h C, Holzinger D, de Jesus AA, Tariq Z, Picarsic J, et al. Interleukin-18 diagnostically distinguishes and pathogenically promotes human and murine macrophage activation syndrome. Blood. 2018;131:1442-55.

17. Yamamoto T, Moriwaki Y, Matsui K, Takahashi S, Tsutsui H, Yoshimoto T, et al. High IL-18 (interferon-gamma inducing factor) concentration in a purine nucleoside phosphorylase deficient patient. Arch Dis Child. 1999:81:179-80.

18. Kawashima M, Novick D, Rubinstein M, Miossec P. Regulation of interleukin18 binding protein production by blood and synovial cells from patients with rheumatoid arthritis. Arthritis Rheum. 2004;50:1800-5. 
19. Grom AA, Horne A, De Benedetti F. Macrophage activation syndrome in the era of biologic therapy. Nat Rev Rheumatol. 2016;12:259-68.

20. Buatois V, Chatel L, Cons L, Lory S, Richard F, Guilhot F, et al. Use of a mouse model to identify a blood biomarker for IFNgamma activity in pediatric secondary hemophagocytic lymphohistiocytosis. Transl Res. 2017;180:37-52.

21. Bracaglia C, de Graaf K, Pires Marafon D, Guilhot F, Ferlin W, Prencipe G, et al. Elevated circulating levels of interferon- $\gamma$ and interferon- $\gamma$ induced chemokines characterize patients with macrophage activation syndrome complicating systemic juvenile idiopathic arthritis. Ann Rheum Dis. 2017:76:166-72.

Ready to submit your research? Choose BMC and benefit from:

- fast, convenient online submission

- thorough peer review by experienced researchers in your field

- rapid publication on acceptance

- support for research data, including large and complex data types

- gold Open Access which fosters wider collaboration and increased citations

- maximum visibility for your research: over $100 \mathrm{M}$ website views per year

At BMC, research is always in progress.

Learn more biomedcentral.com/submissions 